\title{
Continuous Monitoring of Blood Sugar in Brittle Diabetics
}

\author{
G.S. SPATHIS \\ Department of Metabolic Diseases, St. Thomas Hospital, London, Great Britain
}

Received: October 17, 1969

Summary. The blood glucose was measured continuously for periods of up to twenty-nine hours in five patients. The method, which does not require heparinization of the patient, is described. - Three unstable diabetics were investigated. In two, diabetic control was considerably improved as a result of alterations made to their therapeutic regime following this investigation. The symptoms of the third diabetic patient were due to complications of diabetes rather than to the disease itself. The results in these three patients are contrasted with those obtained in two acromegalics (one of whom was also diabetic). Attention is drawn to the occurrence of fasting hyperglycaemia in the early hours of the morning in the brittle diabetics and to the rapidity with which the blood glucose rises. It is thought that growth hormone is not directly responsible for this hyperglycaemia, since marked insulin sensitivity is maintained. stables

Contrôle continu de la glycémie chez des diabétiques in-

Résumé. La glycémie a été mesurée continuellement pendant des périodes allant jusqu'à $29 \mathrm{~h}$ chez 5 malades. On décrit la méthode qui n'exige pas l'héparinisation du malade. - Trois diabétiques instables ont été étudiés. Chez deux d'entre eux l'équilibre diabétique a été considérablement amélioré par suite des modifications apportées à leur régime thérapeutique qui a suivi cette investigation. Les symptômes du troisième diabétique étaient dus à des complications du diabète plutôt qu'au diabète lui-même. - Les résultats chez ces trois patients sont comparés avec ceux obtenus chez deux acromégales (dont l'un était aussi diabétique). On attire l'attention sur l'apparition de l'hyperglycémie à jeun dans les premières heures de la matinée chez les diabétiques instables et sur la rapidité avec laquelle la glycémie s'élève. On pense que I'hormone de croissance n'est pas directement responsable de cette hyperglycémie, puisqu'une sensibilité marquée ì l'insuline est maintenue.

\section{Dauermessung der Blutzuckerspiegel bei labilen Dia-} betikern

Zusammenfassung. Bei 5 Patienten wurden die Blutzuckerspiegel fortlaufend über Zeiträume von bis zu 29 Std. bestimmt. Die Methodik, die keine Heparinisierung des Patienten erforderlich macht, wird beschrieben. Drei nicht stabile Diabetiker wurden untersucht. Bei zwei Patienten besserte sich die Diabetes-Einstellung beträchtlich auf Grund von Änderungen in der Therapie, die auf Grund dieser Untersuchungsergebnisse vorgenommen wurden. Die Symptome des dritten Diabetikers waren in erster Linie auf Diabeteskomplikationen und nicht so sehr auf die Krankheit selbst zurückzuführen. Die Ergebnisse bei diesen drei Patienten werden mit denen von 2 Akromegalen verglichen, von denen einer ebenfalls einen Diabetes aufwies. Es wird besonders auf das Vorkommen einer Nüchtern-Hyperglykämie in den frühen Morgenstunden bei labilen Diabetikern und auf die Geschwindig. keit des Blutzuckeranstieges hingewiesen. Es wird angenommen, daß das Wachstumshormon nicht direkt für diesen Blutzuckeranstieg verantwortlich ist, da die Insulinempfindlichkeit erhalten bleibt.

Key-words: Continuous blood glucose analysis in vivo, brittle diabetics, acromegalics, effect of insulin, fasting hyperglycaemia.
Some diabeties are notoriously difficult to control and no single standardized regime is adequate for the management of all patients. In some patients, the inability to establish a satisfactory therapeutic regime may be due to insufficient knowledge of their biochemical profile. Tests normally used to evaluate diabetic control may be inadequate or misleading - for example glycosuria may be due to a low renal threshold for glucose, or a high fasting blood sugar may cause one to disregard the possibility of relative hypoglycaemia occuring during the night. A detailed "blood sugar profile" should assist in the management of such patients.

This paper describes a method successfully used to monitor blood glucose continuously for up to twentynine hours, and reports the results obtained in three diabetics and two acromegalics.

\section{Methods}

Sampling. Blood was sampled continuously and the glucose concentration estimated by an autoanalyser mounted on a special trolley at the bedside.
A double-lumen catheter $[11]$ was used and inserted whenever possible into a vein on the radial aspect of the forearm using Seldinger's technique [9]. An extra line in the manifold of the autoanalyser pumped heparin $(10-50 \mathrm{u} / \mathrm{ml}$ saline at $0.096 \mathrm{ml} / \mathrm{min})$ into the outer lumen of the catheter, the inner tube of which was attached directly to the sample line on the manifold. Through this line, heparinized blood was sampled at $0.32 \mathrm{mI} / \mathrm{min}$; actual blood was, therefore, withdrawn at a rate of $0.244 \mathrm{ml} / \mathrm{min}$ or rather less than $15 \mathrm{ml} / \mathrm{h}$.

\section{Chemical Analysis}

Hill and Kessler's [3] glucose oxidase method was used with the minor modifications previously described [10]. The most important of these was the introduction of pulse suppression into the mixed enzyme-dye line before it met the stream emerging from the dialyser. Without this suppression baseline instability is too great for continuous monitoring. 


\section{Standardization}

Standards were sampled through a catheter at the start and end of every experiment. For convenience a special "standards" catheter was used consisting essentially of a piece of plastic tubing attached to the solitary $\operatorname{limb}$ of a glass " $h$ " piece. Heparin was infused standards approximately four hourly and adjust the baseline. Fig. 1 shows part of an actual recording, during which standards were sampled on two occasions and the baseline adjusted. Using the "standards" catheter for this purpose, it was not necessary to remove the double lumen catheter from the patient.

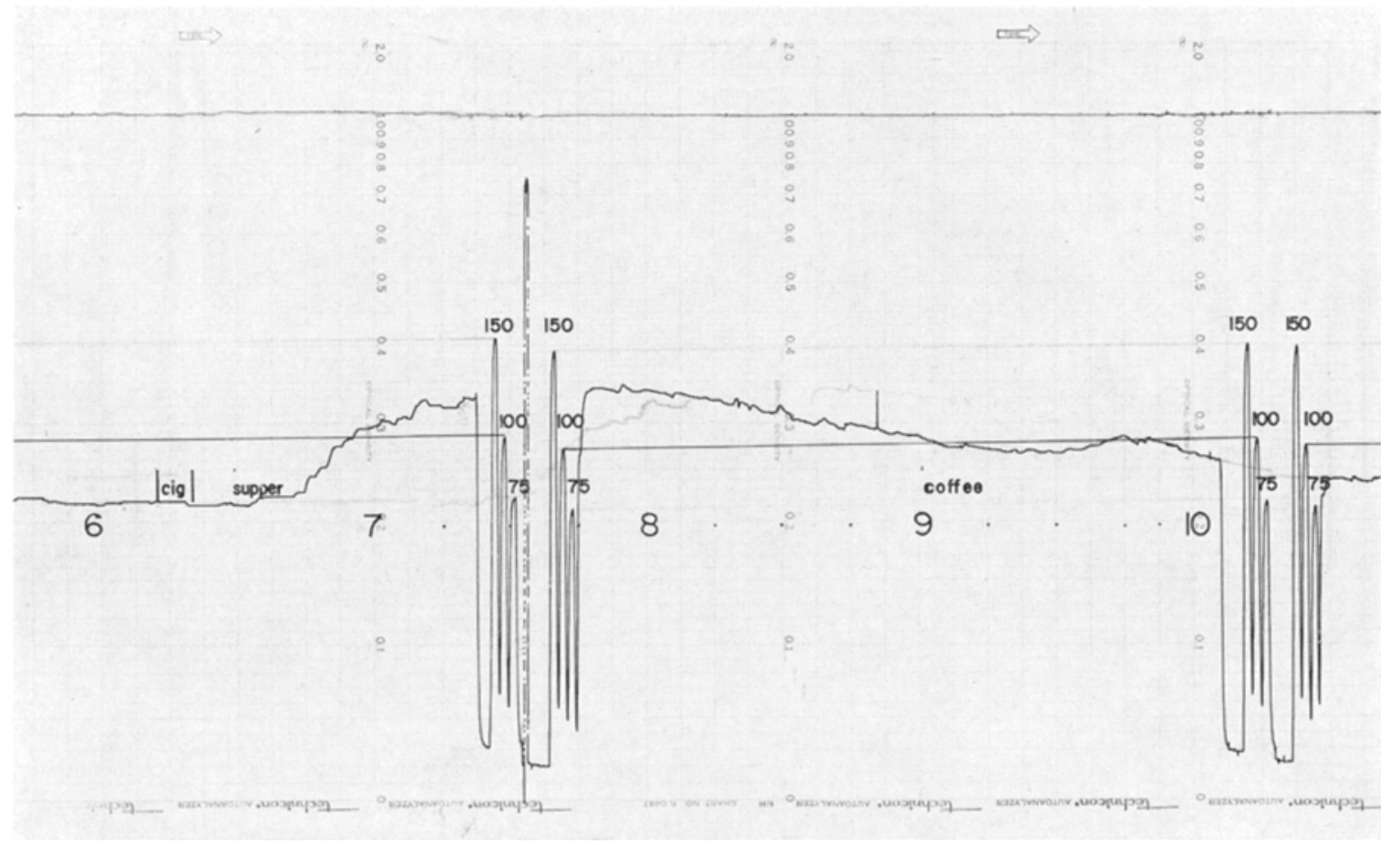

Fig. 1. Part of an actual recording, illustrating standardization and recalibration

into the side arm of the " $h$ " piece and allowed to mix with the standard before being aspirated through the remaining limb. Thus, no correction has to be made for the diluting effect of heparin when sampling blood. As a check at the end of the experiment standards are sampled with the actual double-lumen catheter used, in addition to the "standards" catheter.

Accuracy. Details already published have illustrated the lack of baseline noise and the sensitivity and reproducability of the method [10]. It was possible to detect changes in glucose concentration of less than $2 \mathrm{mg} \%$, and if sampling was interrupted for even one second a recognizable deflection was produced in the recording. It should be stressed, however, that care is required in assembling and maintaining the apparatus to ensure accuracy and sensitivity and that slight baseline noise which may be ignored during intermittent sampling may be unacceptable during continuous monitoring.

With the apparatus used baseline drift has remained a problem despite adjustments to the manifold and care in assembling the autoanalyser. During prolonged experiments it was necessary to sample
Case reports and results

Patients. There were three diabetics and two acromegalics.

Patient 1. Mr. S. aged 32 years. His diabetes had been difficult to control since diagnosis at the age of 18 years, and latterly he had been admitted to hospital three times for investigation of headaches and restabilization following severe hypoglycaemia. He was being treated variously with antidepressants, tranquillisers and ataractics. Continuing glycosuria as an outpatient necessitated increasing insulin dosage. As an in-patient, very high blood sugars alternated with periods of hypoglycaemia. Prior to the investigation reported he had been tried on cortico-steroids for a short while.

Patient 2. Mrs. F. aged 28 years, diabetic since the age of 8 years and always difficult to control, had latterly been on Lente insulin and phenformin. She was admitted for investigation of vomiting and general malaise which had interfered with her occupation as a nurse. As an inpatient her vomiting did not coincide with hypoglycaemic episodes, but she was found to have very variable blood sugar levels. 
Patient 3. Mr. K. aged 56 years. Diabetic since the age of 42 years, he was admitted for investigation of episodes of nocturnal diarrhoea and had evidence of neuropathy and probable early lipoatrophy. His blood sugar had been difficult to control despite various insulin regimes.
Shortly after the observations reported he developed some ketosis with evidence of diabetic neuropathy and retinopathy.

Patient 5. Mr. T. aged 28 years was an acromegalic with normal carbohydrate tolerance but a hyperinsulinaemic response to glucose infusion.

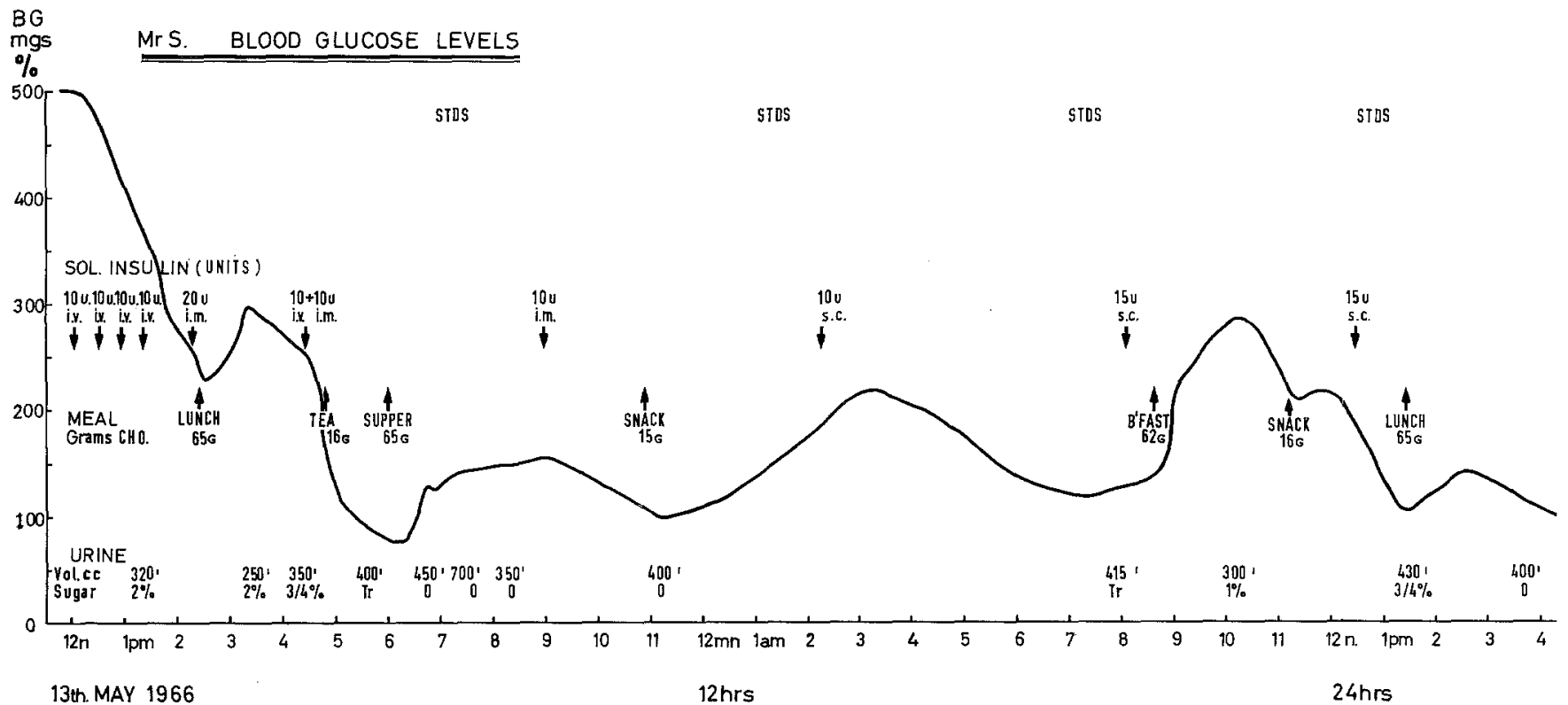

Fig. 2. Patient No. 1. Diabetic

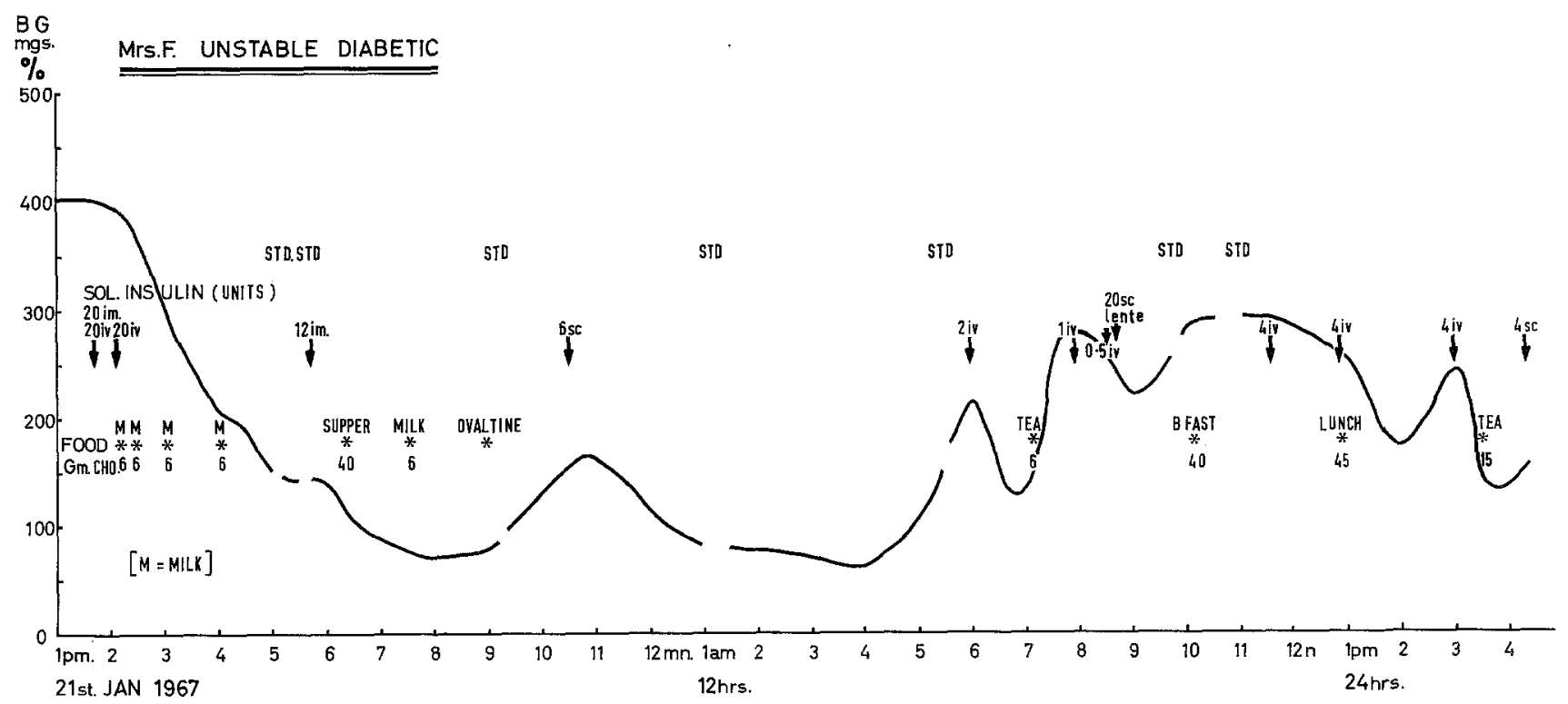

Fig. 3. Patient No. 2. Diabetic

Patient 4. Mr. H. aged 34 years was an acromegalic whose disease was active despite pituitary fossa irradiation some years before. His diabetes was severe, unresponsive to insulin, but controllable without insulin by a rigid diet he was unable to keep to at home.

\section{Results and Treatment}

Blood glucose variations throughout the test period for each patient are illustrated (Figs. 2-4, the diabeties; 5 and 6 the acromegalics). 
With the timing, type and dose of insulin, the carbohydrate load and alterations in blood sugar shown in clear relationship to each other, it is possible to see how a suitable therapeutic regime could be devised for each patient. Patients 1 and 2 showed great sensitivity to insulin and a very labile blood
The results found in the diabetic acromegalic patient 4, are shown in Fig. 5. Though obviously diabetic with a high blood sugar and an excessive response to carbohydrates, there was no rise in his blood glucose while fasting; indeed it fell by about $50 \mathrm{mg} \%$ over $11 \mathrm{~h}$.

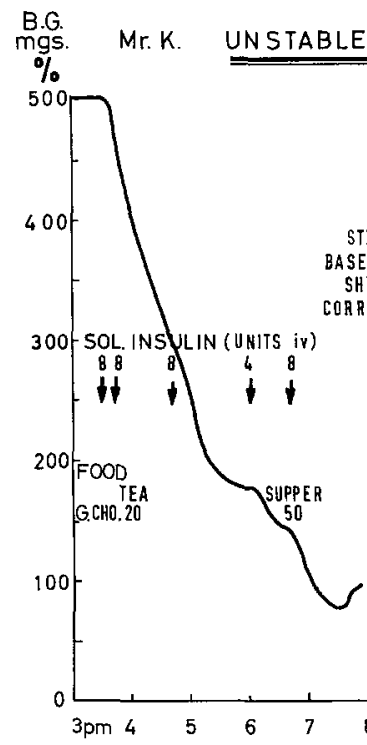

3nd APRIL 1967
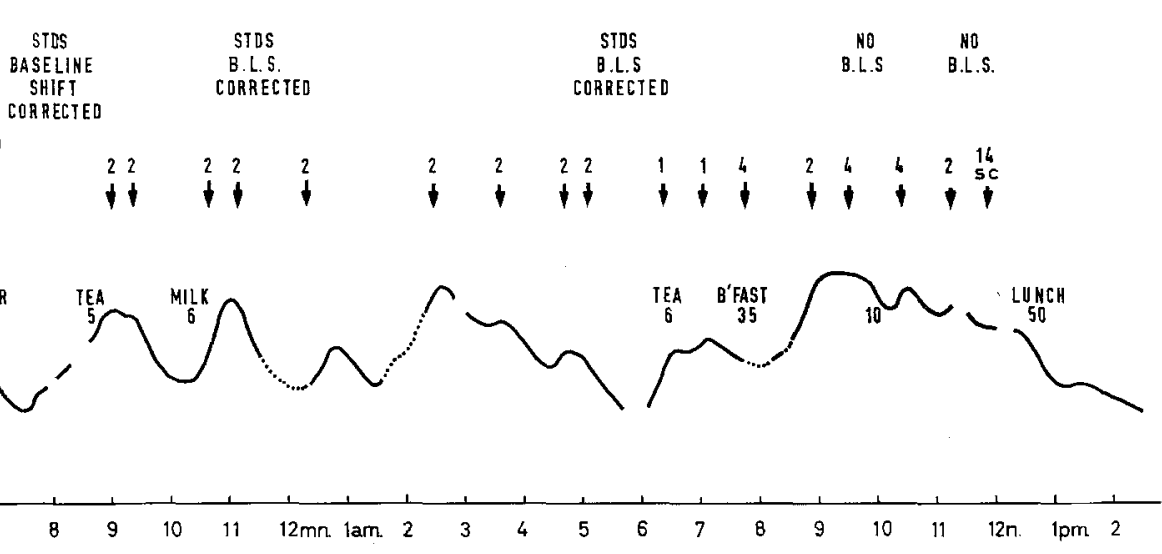

12 hrs.

Fig. 4. Patient No. 3. Diabetic

sugar. Subsequently they were adequately treated with three daily injections of soluble insulin, a small dose of P.Z.I. being added to the midday dose to prevent an early morning rise in blood sugar.

In patient 3, though the effect of intravenous insulin wore off fairly rapidly, the changes in blood sugar were not so marked and occurred more slowly than in the other two. As a result of the investigation this patient was stabilized on a single injection of Lente insulin.

All three patients felt themselves considerably better on their new regimes. Not surprisingly patient 3 continued to have diarrhoea though he was kind enough to claim the attacks were less troublesome. Measurements of his blood sugar did not suggest that his diabetic control had been improved. Both the others, however, remained stable. At follow-up seventeen months after the investigation, patient 1 claimed he had never felt better and had lost no time from work because of his diabetes in the past year - this had never happened to him before. Patient 2 also had had no time off due to illness and her health "has improved considerably". Both patients were free of their previous symptoms (headaches and depression in the case of Mr. S., vomiting and malaise with Mrs. F.).

Attention is drawn to the rising blood sugar seen in these patients while fasting. This is most marked in patient 2 who also shows extreme insulin sensitivity at this time.
Fig. 6 shows the observation made in another acromegalic, patient 5 . The lower dotted tracing is on the same scale as Figs. 2-5; the upper solid tracing is included to show details. This patient had no carbohydrate intolerance, and his results may serve as a control. While fasting, his blood glucose fell by about $6 \mathrm{mg}$ in $6 \mathrm{~h}$. The Figure also shows the effect of inhalation of cigarette smoke (the patient was a nonsmoker).

\section{Methods}

\section{Discussion}

Considerable experience of continuous monitoring has been gained using the catheter previously described $[11,10]$ and the technique has been found relatively simple. The observations recorded here show that it is possible to sample blood continuously for several hours without injecting heparin. Only one other group of workers have published results of monitoring blood glucose changes for more than a few hours and they found it necessary to heparinize their patients [5]. In metabolic investigations it would seem preferable not to inject heparin, which is known to affect lipid [1] and sodium [8] metabolism and has been found to affect insulin-like activity in vitro [2].

This technicue of continuous analysis offers several advantages. Since the result is recorded within seven minutes of sampling it allows one to adjust the insulin dosage to maintain the blood sugar within predeter- 
mined limits. It is possible to see the exact onset and duration of action of any insulin injection. The relationship of the blood glucose to any symptom or sign (e.g. glycosuria) is obvious (Mrs. F, patient No. 2, was in Mrs. F.) would have been missed with intermittent sampling, even as frequently as hourly.

One drawback of the method is that unsatisfactory sampling can of itself produce a deflection in the trace.

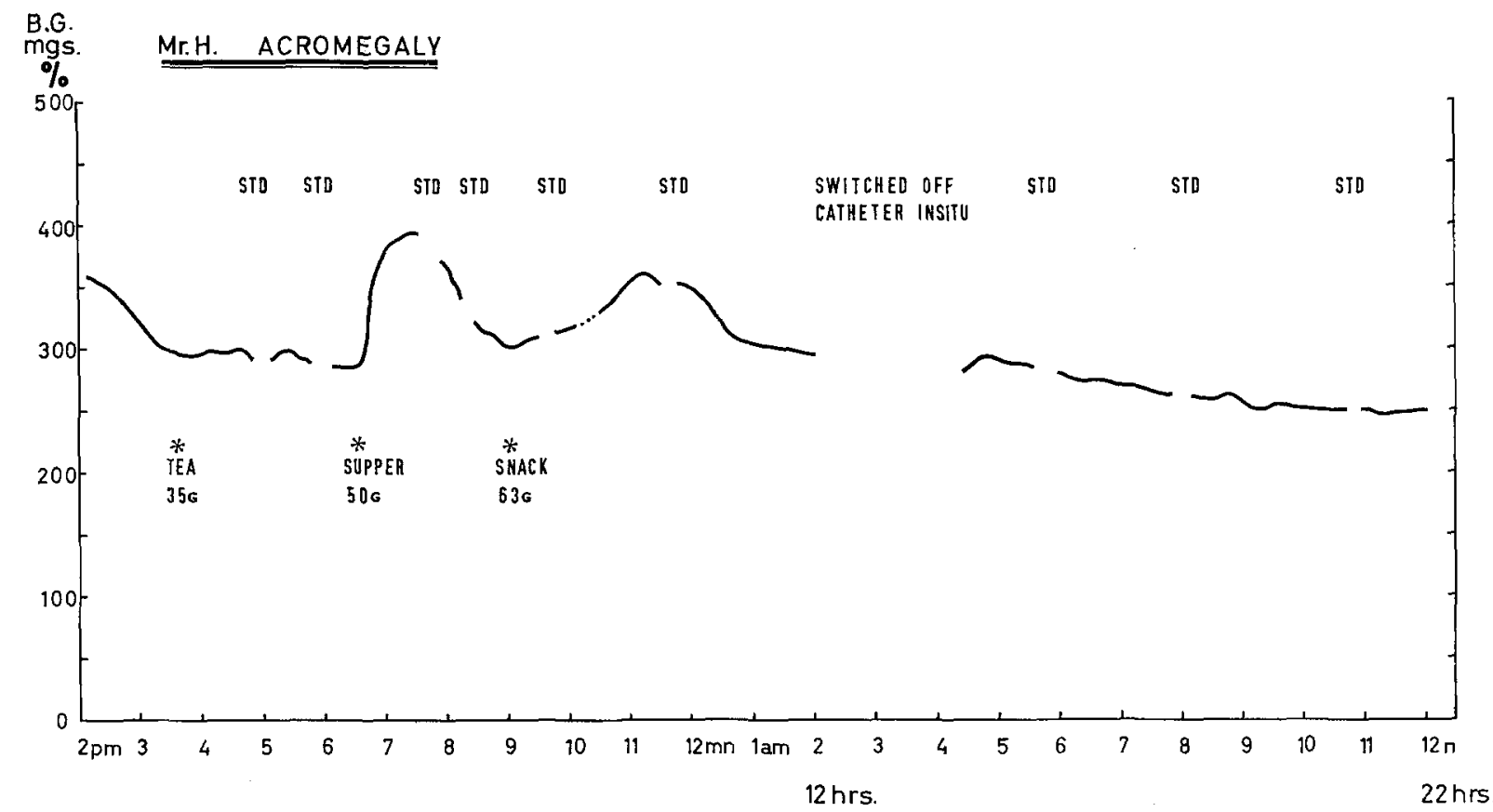

Fig. 5. Patient No. 4. Diabetic and Acromegalic

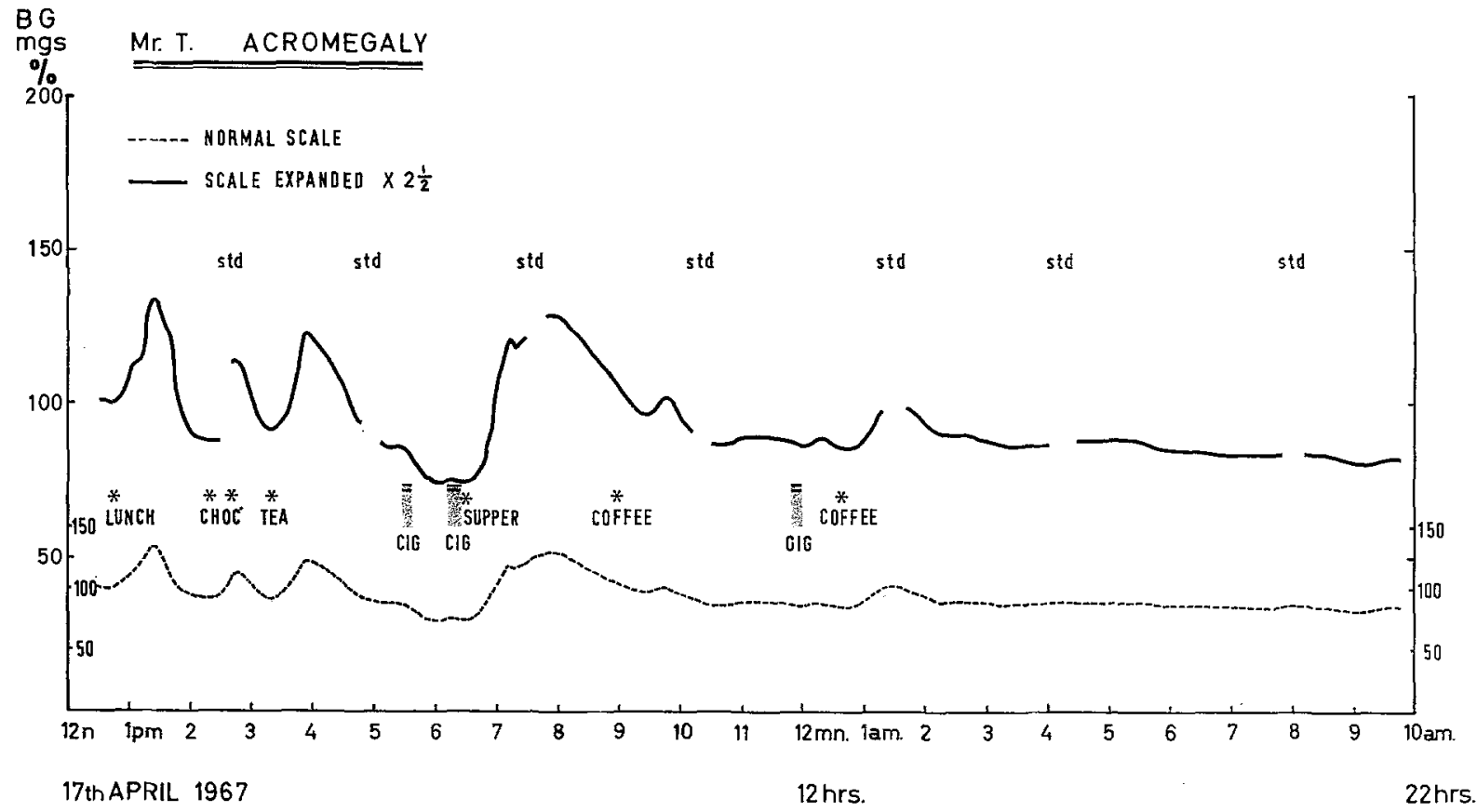

Fig. 6. Patient No. 5. Acromegalic with normal carbohydrate tolerance

found to have a previously unsuspected low renal threshold for glucose; the lability of her blood sugar levels had helped to obsure this). Finally, the short lived, though marked effect, of insulin (again best seen
With experience it is possible to recognize several types of artefacts [10] (Fig. 7), and inspection of the apparatus and catheters will show the existence of mechanical problems. 


\section{Results}

Though results on only three diabetic patients are reported certain conclusions can be drawn.
The factors responsible for the rapid rise in fasting blood glucose are not clear. The effect of insulin is short lived in these patients compared with normals or diabetic acromegalics. It is possible that insulin is degraded

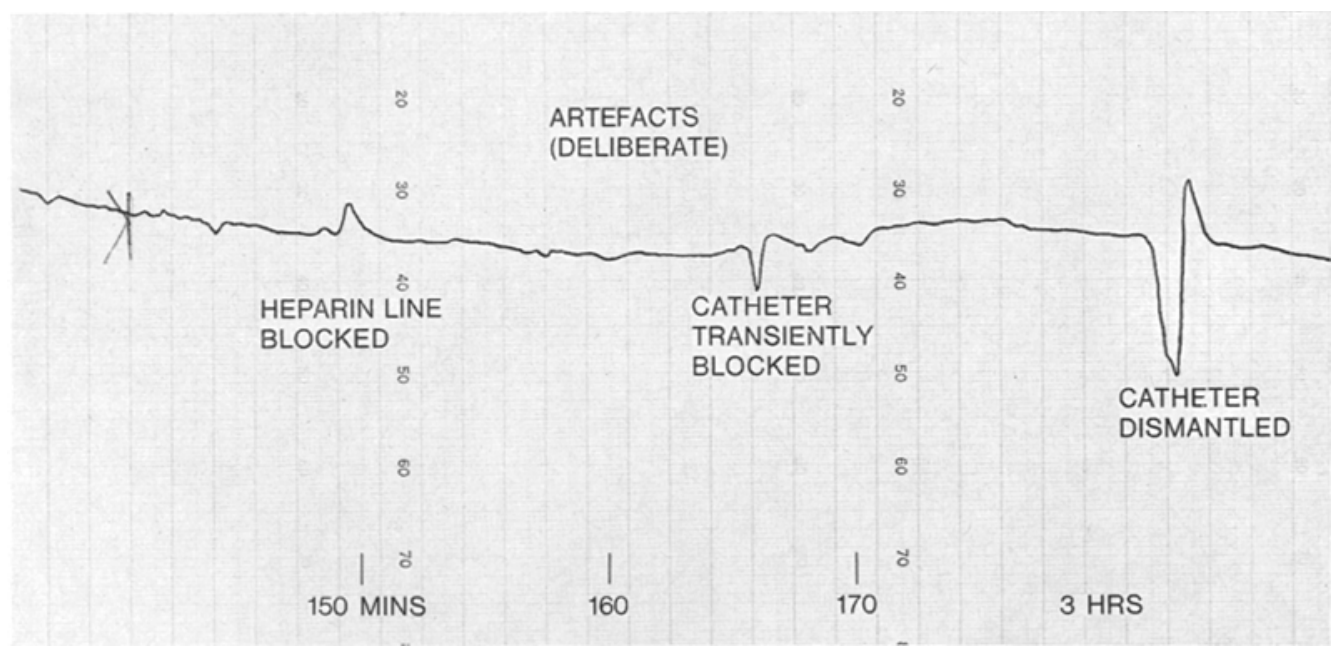

Fig. 7. Part of an actual recording to illustrate recognizable artefacts

Fasting hyperglycaemia is well recognized in diabetics but the rapidity with which the blood glucose rose was surprising. In patient No. 2 the blood glucose spontaneously rose by $140 \mathrm{mg} \%$ in $120 \mathrm{~min}$ to $225 \mathrm{mg} \%$ and this rate of rise showed no tendency to slow down. In my experience even severe induced hypoglycaemia in normals does not lead to so prompt a rise in the blood glucose. Two units of insulin intravenously caused an immediate fall (from $225 \mathrm{mg} \%$ to $125 \mathrm{mg} \%$ within forty-five minutes) showing that she was still very sensitive to insulin. However, the blood sugar started to rise again at this point, apparently as rapidly as before. In contrast, two severely diabetic, partially hyphophysectomized, acromegalics showed a fall in their blood glucose of $45 \mathrm{mg} \%$ in $50 \mathrm{~min}$, after an injection of insulin ( $0.1 \mathrm{u} / \mathrm{kg}$ body weight), but the sugar then remained at this new level for up to three hours (unpublished observation).

Obviously there is a very rapid release of glucose into the blood in some diabetics. It is unlikely that Growth Hormone itself causes this hyperglycaemia, since marked sensitivity to insulin is maintained. Oakley et al. [6] found in a group of diabetics a rise of fasting blood sugar of $76 \mathrm{mg} \%$ over $2 \mathrm{~h}$. Following pituitary ablation with ${ }^{90}$ yttrium, they found a diminished rise in blood glucose over this period, the amount of diminution correlating well with impairment of pituitary function as shown by a diminished growth hormone response to insulin hypoglycaemia. Quabbe et al. [7] found peak growth hormone release in the early morning in normals fasting and asleep. From the results reported here it would appear that any changes in growth hormone accompany rather than determine the changes in blood glucose. more rapidly or that it is bound by circulating antibodies. Alternatively, an abnormal gluconeogenetic or glycogenolytic factor may be present. The work previously quoted [6] suggests that the pituitary is involved and Lentle and Thomas [4] have shown ab. normal pituitary-adrenal function in diabetics.

Acknowledgements: The autoanalysers used were kindly loaned by Technicon Instrument Co. Ltd. and it is a pleasure to acknowledge their generosity. The diabetic patients had been referred by Dr. H.K. Goadby and Dr. B. Creamer, and I would thank them and Professor F. T. G. Prunty for allowing me to investigate them. In addition, I should like to thank Professor Prunty and colleagues in the Department of Chemical Pathology, St. Thomas' Hospital for much helpful encouragement and the Sister and Nursing Staff of Holden Ward for their valuable support.

\section{References}

1. Boberg, J., Carlson, L.A.: Determination of heparin induced lipoprotein lipase activity in human plasma. Clin. chem. Acta. 10, 420-427 (1964).

2. Gunderson, K., Lin, B.J.: Effect of heparin on insulin-like activity in rat bio-assay. Comparison between rat diaphragm and epididymal fat pad assay in normal and untreated diabetic subjects. Diabetes 14, $805-810$ (1965).

3. Hill, J.B., Kessler, G.: An automated determination of glucose utilising a glucose oxidase-peroxidase system. J. Lab. clin. Med. 57, 970-980 (1961).

4. Lentle, B.C., Thomas, J.P. : Adrenal function and the complications of diabetes mellitus. Lancet $\mathbf{1 9 6 4}$ II, $544-549$

5. Molnar, G.D., Aekerman, E., Rosevear, J.W., Gatewood, L.G., Moxness, K.E.: Continuous blood glucose analysis in ambulatory fed subjects. I. general methodology. Mayo Clin. Proc. 43, 833-851 (1968). 
6. Oakley, N.W., Wright, A.D., Fraser, T.R., Haslam, R. M.: Fasting blood-sugar and serum-growth-hormone in hypopituitary diabetics. Lancet 1967 I, $523-525$.

7. Quabbe, H.J., Schilling, E., Helge, H.: Patterns of growth hormone secretion during a 24 -h fast in normal adults. J. clin. Endocr. 26, 1173-1177 (1967).

8. Sealey, J.E., Gerten, J.N., Ledingham, J.G.G., Laragh, J.H.: Inhibition of renin by heparin. J. clin. Endocr. 27, 699-705 (1967).

9. Seldinger, S.I.: Catheter replacement of the needle in percutaneous arteriography. Acta Radiol 39, 368-376 (1953).
10. Spathis, G.S., Hurst, R.J.: Continuous intra-arterial and intra-venous sampling using a simple new catheter ; and its application to blood glucose monitoring in assesment of endocrine disease. Automation in analytical chemistry: Technicon symposia Vol. 2, 275-280 (1966).

11. Spathis, G.S., Hurst, R.J., Pollard, A.: A simple catheter for continuous intravascular sampling. Lancet 1966 II, 266-267.

Dr. G.S. Spathis Middlesex Hospital London, W.I. Great Britain 